\title{
Condyloma acuminata of the urinary bladder: A rare case report
}

\section{Mesanede kondiloma aküminata: Ender bir olgu sunumu}

\author{
Caner EDiZ ${ }^{1}$, Ayşe Nur iHVAN² ${ }^{2}$ Oğuzhan GÜNDÜZ ${ }^{1}$, Hakan Remzi DiNÇER ${ }^{1}$
}

\begin{abstract}
Condyloma Acuminata (CA) is a sexually transmitted disease caused by the Human Papilloma Virus (HPV) of the papovavirus family and it can be seen on the genital or perianal area, sometimes the external urethral orifice or the bladder. Involvement of bladder is very rare and it may be related with immnuosuppression. In our case, the patient came to the hospital with genital lesions and urinary irritation symptoms such as dysuria and pollakiuria. Genital warts were located in the genital area, therefore we took excisional biopsy. And then, the lesions were treated with bipolar cauterization. Cystoscopy was performed to check for involvement of urinary system. There was hyperemia in the base of the bladder and the inter trigonic line and there was an increase in vascularization. We took cold cup punch biopsies from several suspicious areas. The pathological results of external genital warts and bladder biopsies were found consistent with condyloma acuminata. The lesions in the bladder were fulgurated and immunotherapy was performed to prevent recurrence of CA.
\end{abstract}

Keywords: Condyloma acuminata, bladder, treatment öz

Kondiloma aküminata, papovirüs ailesinde yer alan human papilloma virüsün (HPV) neden olduğu seksüel geçişli bir hastalık olup genital ya da perianal bölgede bazende external orifis ve mesane içerisinde görülmektedir. Mesane tutulumu son derece enderdir ve bu durum immünsupresyon ile ilişkili olabilmektedir. Bu olgumuzda, genital lezyon ile beraber dizüri ve pollaküri gibi semptomlar nedeniyle hastanemize başvuran bir hastayı sunduk. Genital alandaki lezyondan eksizyonel biyopsi alındı. Daha sonra lezyonlar bipolar koter ile yakıldı. Üriner sistem tutulumu açısından sistoskopi yapıldı. Mesane tabanı ve inter trigonik alanda hiperemi ve vaskülarizasyonda artış saptandı. Şüpheli alanlardan soğuk biyopsi örneği alındı. Genital alandaki ve mesanedeki lezyonların patolojik incelemesi kondiloma aküminata ile uyumlu olarak bulundu. Mesanedeki lezyonlar fulgarize edildi ve hastaya rekürrens oluşumunu engellemek açısından immünoterapi başlandı.

Anahtar kelimeler: Kondiloma aküminata, mesane, tedavi

\section{INTRODUCTION}

Condyloma Acuminata (CA) is associated with Human Papilloma Virus (HPV). It occurs commonly in external genital areas and sometimes in the urinary system. The lesions may appear as single entities or form typically soft and papillary cauliflower-like clusters. Diagnosis of the lesions are made by visual and histopathological examination of suspected genital areas.

Here, we report a case of condyloma acuminata in the bladder of a 55-year-old woman who came to our clinic with genital lesions and and urinary irritation symptoms such as dysuria and pollakiuria.

\section{CASE}

A 55-year-old married woman registered to our clinic with genital lesions, dysuria and pollakiuria. She had not previously suffered from similar illnesses, and immunosuppression. Her partner was healthy. During physical examination, a few number of warts were found around the genital area. Biochemical findings

Received: 15.12 .2015

Accepted: 13.01.2016

${ }^{1}$ Department of Urology Uskudar State Hospital

${ }^{2}$ Department of Pathology Uskudar State Hospital

Yazışma adresi: Caner Ediz, Department of Urology Uskudar State Hospital, Istanbul

e-mail: drcanerediz@hotmail.com 
and urinalysis were normal. We took some excisional biopsies from the papillary genital lesions. Subsequent to the biopsies, cauterization was performed for the warts. To determine the presence of intravesical involvement, cystoscopy was performed. Some hyperemic areas were found in the base of the bladder and the intertrigonic line. We took several cold cup punch biopsies from these areas, then, the suspicious areas were fulgurated by bipolar loop electrodes. Histopathological examination of genital lesions and the base of the urinary bladder were consistent with the diagnosis of "Condyloma Acuminata". Large stalked papillary and villous structures were found in the genital biopsy (Figure 1) and the punch biopsy of urinary bladder and genital area biopsy (Figure 2 and 3 ) showed the presence of branching and koilocytosis.

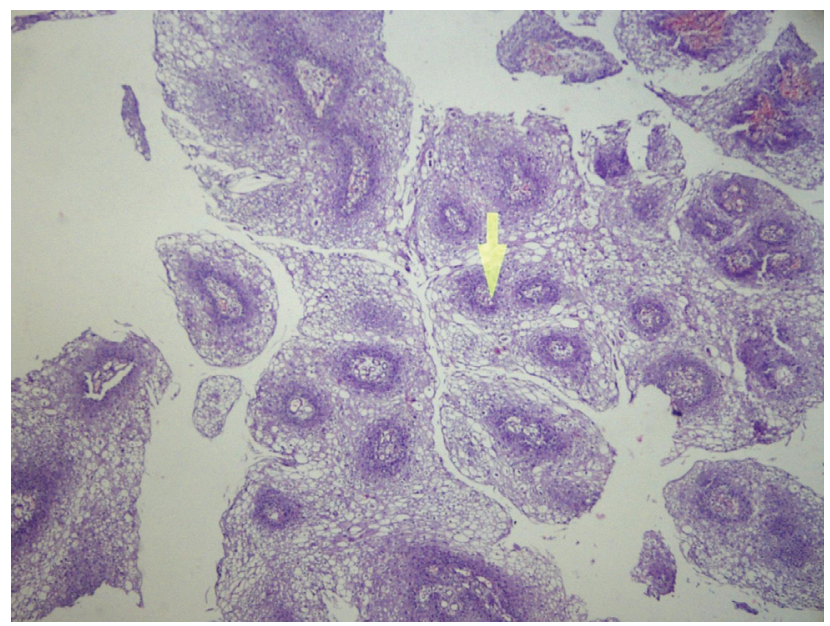

Figure 1. H\&Ex40, Large handle papillaryand villous structures.

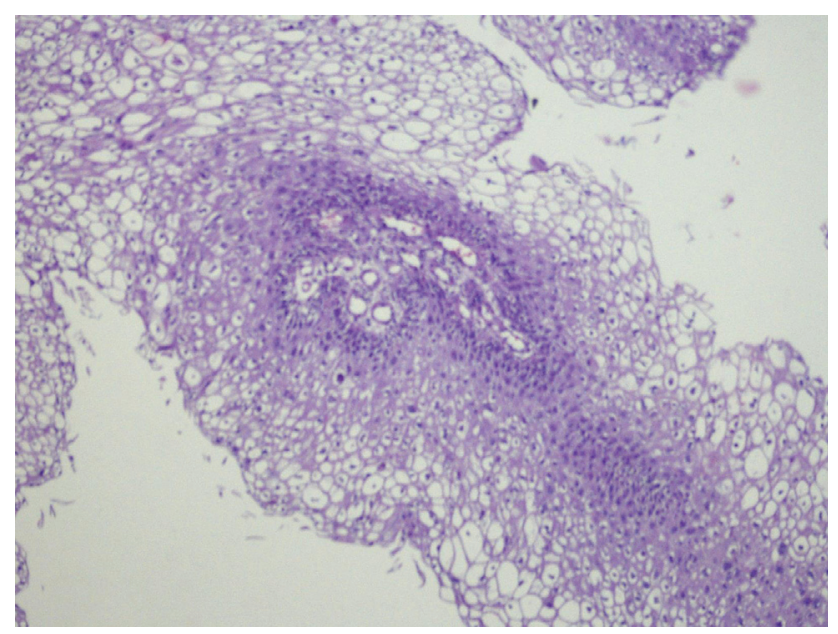

Figure 2. H\&Ex100, Papillary structures.

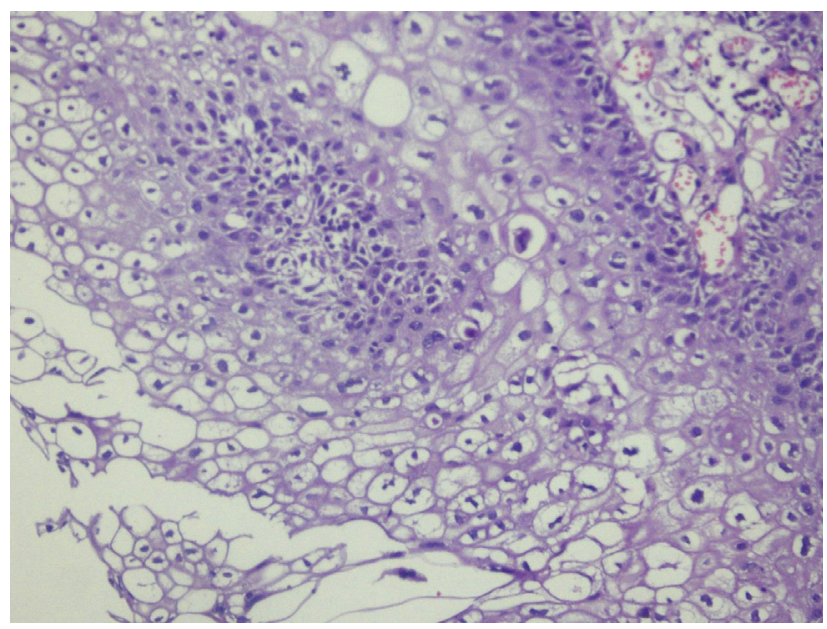

Figure 3. H\&Ex200, Koilocytosis (Vacuolization).

We performed cauterization accordance with the procedure. The immunotherapy was started. Betaglucan therapy was preferred at recommended daily doses of $10 \mathrm{mg}$ for 1 month. After three months from the beginning of the treatment, we performed cystoscopy again. There were no suspicious areas in the base of bladder and trigon line, therefore we ceased immunotherapy.

\section{DISCUSSION}

Condyloma Acuminata is a HPV induced lesion. There are over 100 types of HPV. 14 types are known to cause cancer such as types 16 and 18 . However, 90\% of all genital warts are related with types 6 and 11 . HPV is a common sexually transmitted disease but sometimes sexual contact is not always a necessary prerequisite for infection. Contamination with HPV may be enough. Highest recurrence rates and risk are detected in the $2^{\text {nd }}$ and $3^{\text {rd }}$ stages of the disease. Risk factors are early start-up of sexual activity, multiple sexual partners, history of sexually transmitted diseases, and immunosuppression ${ }^{1}$. The lesions are usually papillary, however flat lesions can rarely be seen $^{2}$. In this case, both of the versions of CA are specified.

HPV infection is usually asymptomatic. When the lesions are visible on the genital areas, patients have to register to the nearest hospital. Urinary system is 
usually sterile. In the patients with cutaneous condyloma acuminatum ${ }^{3}$, the lesion usually arises from the extension of urinary tract. These patients have urinary tract symptoms such as dysuria, pollakiuria and urgency. Our patient was treated with oral antibiotics two times. However her complaints did not improve so after physical examination of genital areas, we decided to perform cystoscopy, suspecting that the urinary bladder or urethra might be infected. History of immunosuppression facilitated development of intravesical infection. Maintenance of immunosuppressive treatment has been associated with this condition. When we reviewed 16 cases of bladder condyloma, five (31\%)4 of the patients had a history of immunosuppression. But in our case, there were no history of immunosuppressive treatment.

HPV is commonly diagnosed clinically. During physical examinations, typical lesions can be seen. Laboratory, radiologic and cystoscopic findings are nonspecific and may be similar to those seen in other urinary system tract diseases. HPV induced carcinoma of bladder may cause filling defect seen during radiological examination such as intravenous pyelography. Also, visual examination and clinical suspicion helped to diagnose urinary tract involvement in this case.

Its histopathological findings consist of superficial hyperkeratosis, thickening of the epidermis (acanthosis), branching, villous and papillary connective tissue stroma. Vacuolisation observed in spinose cells (koilocytosis) is a characteristic feature of HPV infection5. In our case, koilocytosis was diagnosed with histopatological examination of the urinary bladder biopsy materials.

Treatment of CA is very simple but difficult. There is no single curative treatment for condylomata acuminata. Treatment is reserved for patients with visible warts. Noninvasive or invasive treatment options are preferable. The selection of the treatment option depends on the size, morphology, number, and anatomic site of the lesion. If the patient has some symptoms of urinary tract infection, then cystoscopy can be performed. Suspicion is important to determine infection of urethra or urinary bladder. We preferred cauterization of genital and bladder lesions. Immunotherapy is not necessary, but the recurrence and progress of the disease can be reduced with this treatment. Combination of invasive interventions and drug treatments were found to have long term effectiveness. Isoprinosine can be used for the immunomodulating treatment. This study showed that the relapse rate was significantly reduced with isoprinosine treatment from $32 \%$ to 7 percent $^{6}$. Beta Glucan is another immunomodulater option to avoid of reccurrence. Beta Glucan treatment has an effect both antiviral and immunomodulator ${ }^{7}$. So we starterd beta glucan treatment to avoid reccurence of warts for $10 \mathrm{mg}$ per day for one month. Also, new surgical methods can be used for CA, and the YAG laser ablation combined with intraurethral perfusion of 5-fluorouracil is an effective and safer therapy with a lower relapse rate for intraurethral $\mathrm{CA}^{8}$. Thulium laser and $\mathrm{Nd}$ :YAG laser are other safe treatment options when urinary system is involved ${ }^{9}$. This method may be effective when bladder is involved.

The usage of condoms might reduce the risk for HPVassociated diseases. Also prophylactics can reduce of HPV-associated clinical diseases. There are two types HPV vaccine which are bivalent and quadrivalent. Quadrivalent vaccines are also directed against HPV 6 and HPV $11^{10}$. Although the vaccine is efficient, marital status is an important aspect for relapse rates for this patient group. Coskuner et al's study has shown the relationship between marital status and relapse of lesions ${ }^{11}$. So considering this situation, we can't suggest this vaccine to a patient.

From the age of 20, HPV is especially common in sexually active people. Genital warts and urinary tract symptoms should be examined to find out the involvement of the urinary system. Diagnosis and treatment methods must be chosen for urinary tract lesions. After the treatment, we can discuss alternative protective options with the patients and it is up to the patient to choose one the given options. 


\section{REFERENCES}

1. Brummeisl W, Lausenmeyer E, Weber F, et al. Urethral condylomata acuminata. Urologe A 2015;54:378-84. http://dx.doi.org/10.1007/s00120-014-3619-9

2. Karim RZ, Rose BR, Brammah S, Scolyer RA. Condylomata acuminata of the urinary bladder with HPV 11. Pathology 2005;37:176-8. http://dx.doi.org/10.1080/00313020500058615

3. Keating MA, Young RH, Carr CP, et al. Condyloma acuminatum of the bladder and ureter: case report and review of the literature. J Urol 1985;133:465-7.

4. Del Mistro A, Koss LG, Braunstein J, et al. Condyloma accuminata of the urinary bladder. Natural history, viral typing, and DNA content. Am J Surg Pathol 1988;12:205-15. http://dx.doi.org/10.1097/00000478-198803000-00006

5. McKee PH, J. Calonje JE, Granter SR. Pathology of the skin. Fourth edition, 2012.

6. Nejmark BA, Kondrat'eva JS, Zologina VS, Torbik DV. Effectiveness of combined treatment of HPV infection. Urologia 2015;2:39-40.
7. Jung K, Ha Y, Ha SK, et al. Antiviral effect of Saccharomyces cerevisiae beta-glucan to swine influenza virus by increased production of interferon-gamma and nitric oxide. J Vet Med B Infect Dis Vet Public Health 2004;51:72-6. http://dx.doi.org/10.1111/j.1439-0450.2004.00732.x

8. Ge CG, Jiang J, Jiang $Q$, et al. Holmium: YAG laser ablation combined intraurethral fluorouracil perfusion as treatment option for intraurethral condyloma acuminata in men. Minerva Urol Nefrol 2014;66:77-81.

9. Blokker RS, Lock TM, de Boorder T. Comparing thulium laser and $\mathrm{Nd}$ :YAG laser in the treatment of genital and urethral condylomata acuminata in male patients. Lasers Surg Med 2013;45:582-8. http://dx.doi.org/10.1002/Ism.22181

10. Skerlev M, Ljubojevic S. The specifities of the HPV-genital infections in males. Med Glas (Zenica) 2010;7:89-95.

11. Coskuner ER, Ozkan TA, Karakose A, et al. Impact of the quadrivalent $\mathrm{HPV}$ vaccine on disease recurrence in men exposed to HPV infection: a randomized study. J Sex Med 2014;11:2785-91.

http://dx.doi.org/10.1111/jsm.12670 